\title{
Kinerja Reaktor Hibrid Anaerob pada Kecepatan Tinggi dalam Mengolah Air Limbah Molasse
}

\author{
(Performance of High Rate Anaerobic Hybrid Reactor on \\ Treatment of Molasse)
}

\author{
Gede H. Cahyana, Asis H. Djajadiningrat
}

\begin{abstract}
This research describes the performance of a laboratory scale anaerobic hybrid reactor (so called as Rehan) that combines an upflow anaerobic sludge blanket (UASB) in lower part and AF (anaerobic filter) filled with gravel or pebble in upper part of the reactor. It was operated at ambient temperature and high organic loading rate that varied from 8.26 to $34.05 \mathrm{~g} / \mathrm{l}$.day with average hydraulic retention time of 30 hours. The results showed that Rehan could achieve COD conversion of $50.19 \%$ to $79.34 \%$ with no sludge recirculation and $79.88 \%$ to $85.72 \%$ in mode of returned sludge. And so, a special phenomenon came up in the bottom of Rehan i.e. in suspended growth zone where the reduction of organic pollutant up to $65 \%$. In this zone, the sludge concentration or volatile suspended solid was very high. But, when the organic loading about 40,000 mg/l COD, the performance of Rehan steeply came down, its efficiency became $50.19 \%$. Nevertheless, in general, Rehan could treat the organic waste up to $25,000 \mathrm{mg} / \mathrm{l} \mathrm{COD}$.
\end{abstract}

Keywords: Rehan, hybrid, organic loading, suspended, attached growth.

\section{Pendahuluan}

Selain bioproses aerob, dalam pengolahan air limbah juga bisa dan biasa diterapkan bioproses anaerob khususnya reaktor modern atau berkecepatan tinggi (high rate) seperti UASB (upflow anaerobic sludge blanket), AF (anaerobic filter), dan hibrid. Semua reaktor anaerob modern tersebut memiliki alur degradasi zat organik yang sama dengan reaktor anaerob kuno seperti digester. Yang berbeda hanyalah laju degradasinya.

Reaktor hibrid, dalam riset ini disebut Rehan (reaktor hibrid anaerob), adalah reaktor bastar antara UASB dan AF yang dikembangkan untuk mereduksi biomassa hanyut (washout) yang terjadi pada UASB. Namun demikian, grup Wageningen, yaitu kumpulan pakar anaerob khususnya UASB dari Universitas Wageningen Belanda menyatakan gagal mengolah air limbah dengan reaktor hibrid ini. Sebaliknya Reynold dan Colleran melaporkan keberhasilannya mengolah air limbah dengan Rehan yang COD-nya 10.000 mg/l. Mereka memperoleh efisiensi yang lebih tinggi daripada reaktor upflow atau downflow fixed bed (Lettinga, Hulshoff, 1991). Adapun Ozturk et.al., (1993) membebani Rehannya dengan air limbah pabrik susu yang efisiensinya pada 
kecepatan pembebanan organik (KPO) 8,5 g/l.hari adalah $87 \%$. Kesuksesan Rehan juga ditulis oleh Speece (1996) dengan mengutip observasi Patrick et.al. pada Rehan bervolume $3.400 \mathrm{~m} 3$, yang $1 / 3$ bagiannya tersuspensi dan $2 / 3$ bagiannya bermedia plastik (125 m2/m3). Efisiensinya $80 \%$ pada COD $18.000 \mathrm{mg} / \mathrm{l}$ dengan waktu tinggal hidrolis 50 jam.

Oleh karena itu, dapat dikatakan bahwa Rehan menawarkan penggabungan kelebihan atau keuntungan UASB dan AF dan berhasil mengolah limbah yang terlarut (soluble) maupun sebagian taklarut (insoluble) daripada reaktor jenis lain. Di antara kelebihannya itu adalah KPO-nya lebih besar daripada yang mampu diterima oleh AF, biobutirnya lebih mudah dikultivasi (ditanam dan dikelola) daripada UASB dan start upnya lebih singkat daripada fluidized bed. Medianya dapat dipilih yang punya kapasitas pelekatan tinggi (high biomass attachment capacity) seperti porus dan rasio luas per volumenya juga tinggi.

\section{Metode dan bahan}

Rehan dibuat dari pipa PVC, terdiri atas dua bagian, yaitu bagian bawah berdiameter $20 \mathrm{~cm}$, tinggi $35 \mathrm{~cm}$ yang difungsikan sebagai pertumbuhan tersuspensi (identik dengan UASB). Di bawah segmen ini dipasang distributor aliran berbentuk kerucut setinggi $15 \mathrm{~cm}$ dan inletnya berupa pelat berlubang (perforated plate). Volume total bagian bawah ini 14,4 I. Segmen atasnya berdiameter $25 \mathrm{~cm}$, tinggi efektif $110 \mathrm{~cm}$, berisi kerikil ukuran $2-3 \mathrm{~cm}$ sebagai media pertumbuhan lekat (identik dengan anaerobic filter atau fixed bed atau biofilter). Porositas bagian lekat ini 0,50 sehingga volume efektifnya $27,15 \mathrm{I}$. Rasio volume segmen tersuspensi terhadap terlekat kira-kira $1: 2$ dan jumlah kedua volume tersebut adalah volume total sebesar 41,55 I. Waktu tinggal hidrolisnya didesain 30 jam sehingga debit umpan dari pompa peristaltisnya 23 $\mathrm{ml} / \mathrm{menit}$.

Rehan dibebani air limbah sintetis yang dibuat dari molasse dengan cara pengenceran hingga konsentrasi yang diinginkan, lalu diberi nutrien dari $\mathrm{NH}_{4} \mathrm{Cl}$ dan $\mathrm{K}_{2} \mathrm{HPO}_{4}$. Sebagai larutan penyangga (buffer) $\mathrm{pH}$ ialah $\mathrm{NaHCO}_{3}$ yang dosisnya bervariasi, bergantung pada beban organik influennya. Dimasukkan juga mineral runut (trace mineral) ke dalam umpan dengan formula van Lier (1995). Dalam risetnya, van Lier menggunakan reaktor UASB dan campuran sukrose (komponen utama molasse) dengan asam lemak volatil (volatile fatty acid) sebagai substrat dengan konsentrasi sangat tinggi (135.000 mg/l COD) pada kondisi termofilik. Mineral runut yang 
ditambahkan pada COD $135.000 \mathrm{mg} / \mathrm{l}$ adalah $26,7 \mathrm{ml} / \mathrm{l}$ umpan dan 13,3 $\mathrm{ml} / \mathrm{l}$ umpan pada COD 67.500 mg/l. Pada Rehan ini untuk COD $10.000 \mathrm{mg} / \mathrm{l}, 25.000 \mathrm{mg} / \mathrm{l}$ dan $40.000 \mathrm{mg} / \mathrm{l}$ dosisnya masing-masing: $2 \mathrm{ml} / \mathrm{l}, 5 \mathrm{ml} / \mathrm{l}$ dan $8 \mathrm{ml} / \mathrm{l}$ umpan.

\section{Hasil dan pembahasan}

Ada lima konsentrasi atau beban organik riil dalam bentuk COD yang diumpankan ke dalam Rehan, yaitu 10.650 mg/l, 25.200 mg/l, 42.560 mg/l, 10.330 mg/l dan 11.755 $\mathrm{mg} / \mathrm{l}$. Tiga beban pertama bermodus tanpa resirkulasi efluen dan dua yang terakhir dengan resirkulasi efluen (lumpur). Semua beban organik dan kecepatan pembebanan organik (KPO) yang diterapkan pada Rehan tersebut ditampilkan pada Tabel 1.

Tabel 1. Beban organik dan kecepatan pembebanan organik Rehan.

\begin{tabular}{|c|c|}
\hline $\begin{array}{c}\text { Beban organik (COD, } \\
\mathrm{mg} / \mathrm{l})\end{array}$ & $\begin{array}{c}\text { Kecepatan pembebanan organik } \\
\mathrm{kg} / \mathrm{m}^{3} \text {.hari atau } \mathrm{g} / \mathrm{l} . \text { hari }\end{array}$ \\
\hline 10.650 & 8,52 \\
\hline 25.200 & 20,16 \\
\hline 42.560 & 34,05 \\
\hline 10.330 & 8,26 \\
\hline 11.755 & 9,40 \\
\hline
\end{tabular}

Sumber: Rencangan penelitian.

\section{Pengaruh KPO dan resirkulasi terhadap efisiensi}

Setiap beban organik yang diaplikasikan ke Rehan mengalami evolusi penurunan konsentrasi ke arah efluen seperti diperlihatkan pada tabel 2. Data ini menunjukkan bahwa beban dan tingkat KPO mempengaruhi efisiensi pengolahan (lihat juga Tabel 3 dan Tabel 4).

Tabel 2. Evolusi COD (mg/l) di sepanjang Rehan.

\begin{tabular}{|l|l|l|l|l|l|l|}
\hline $\begin{array}{c}\text { Titik } \\
\text { sampling }\end{array}$ & \multicolumn{1}{c|}{ influen } & \multicolumn{1}{c|}{ P1 } & \multicolumn{1}{c|}{ P2 } & \multicolumn{1}{c|}{ P3 } & \multicolumn{1}{c|}{ P4 } & efluen \\
\hline Jarak, cm & \multicolumn{1}{c|}{0} & \multicolumn{1}{c|}{22.5} & \multicolumn{1}{c|}{32.5} & \multicolumn{1}{c|}{50} & \multicolumn{1}{c|}{100} & \multicolumn{1}{c|}{160} \\
\hline nir-R & 10.650 & 3.550 & 2.480 & 2.410 & 2.350 & 2.200 \\
\hline nir-R & 25.200 & 7.330 & 6.200 & 5.950 & 5.900 & 5.520 \\
\hline nir-R & 42.560 & 24.000 & 21.600 & 22.800 & 21.600 & 21.200 \\
\hline R=0,71 & 10.330 & 1.760 & 1.755 & 1.710 & 1.475 & 1.475 \\
\hline R=1,58 & 11.755 & 2.440 & 2.425 & 2.420 & 2.400 & 2.365 \\
\hline
\end{tabular}

Keterangan :

nir- $R$ = tanpa resirkulasi

$R=$ rasio resirkulasi.

Pada modus tanpa resirkulasi, lihat Tabel 3, Rehan mencapai efisiensi tertinggi sebesar $79,34 \%$ yang terjadi pada beban COD $10.650 \mathrm{mg} / \mathrm{l}$ atau KPO 8,52 kg/m3.hari 
dengan kecepatan penyisihan $6,76 \mathrm{~kg}$ COD$/ \mathrm{m} 3$.hari. Pada beban $25.200 \mathrm{mg} / \mathrm{l}$ atau KPO 20,16 kg/m3.hari, Rehan masih mampu mencapai efisiensi $78,09 \%$ yang relatif tidak jauh berbeda dengan efisiensi pada beban $10.650 \mathrm{mg} / \mathrm{l}$ dengan kecepatan penyisihan $15,74 \mathrm{~kg}$ COD/m3.hari. Artinya, meski efisiensinya lebih kecil namun penyisihannya lebih cepat 2,3 kali daripada beban pertama. Juga berarti bahwa lebih banyak substrat yang diolah per harinya karena konsentrasi VSS pada beban 25.200 mg/l lebih besar daripada konsentrasi VSS pada beban $10.650 \mathrm{mg} / \mathrm{l}$.

Tabel 3. Dosis $\mathrm{NaHCO}_{3}$ dan efisiensi pengolahannya, tanpa resirkulasi.

\begin{tabular}{|c|c|c|c|}
\hline $\begin{array}{c}\text { Beban organik } \\
(\mathrm{COD}, \mathrm{mg} / \mathrm{l})\end{array}$ & $\begin{array}{c}\mathrm{KPO} \\
\mathrm{kg} / \mathrm{m}^{3} \text {.hari }\end{array}$ & $\begin{array}{c}\text { Dosis } \mathrm{NaHCO}_{3} \\
\mathrm{~g} / \mathrm{l}\end{array}$ & $\begin{array}{c}\text { Efisiensi } \\
\%\end{array}$ \\
\hline 10.650 & 8,52 & 5 & 79,34 \\
\hline 25.200 & 20,16 & 9 & 78,09 \\
\hline 42.560 & 34,05 & 12 & 50,19 \\
\hline
\end{tabular}

Namun hal serupa tidak terjadi pada beban $42.560 \mathrm{mg} / \mathrm{l}$ COD atau KPO 34,05 $\mathrm{kg} / \mathrm{m} 3$.hari. Pada beban ini efisiensinya turun tajam menjadi 50,19\% dengan kecepatan penyisihan 17,09 kg COD/m3.hari. Meskipun nilai ini melebihi kedua nilai sebelumnya, namun tampak tanda-tanda penurunan kinerja reaktor karena konsentrasi asam-asam volatilnya tinggi dan produksi gas serta persentase metananya turun menjadi $41,65 \%$.

Dengan kinerja seperti itu dapat dikatakan bahwa Rehan mampu mengolah zat organik hingga kisaran $25.000 \mathrm{mg} / \mathrm{l}$ atau KPO $20 \mathrm{~kg} / \mathrm{m} 3$.hari tanpa penurunan efisiensi yang signifikan. Tetapi Rehan kurang mampu mendegradasi molasse pada COD 40.000 $\mathrm{mg} / \mathrm{l}$ atau KPO $34 \mathrm{~kg} / \mathrm{m} 3$. hari. Sebab, jika beban ini dilanjutkan maka reaktor akan sour atau "masam" atau pH-nya turun ke tingkat yang tidak nyaman bagi metanogen dan bahkan mematikannya sehingga mengancam operasi reaktor.

Selain akibat KPO-nya yang tinggi, penurunan kinerja juga bisa disebabkan oleh konsentrasi natrium bikarbonatnya yang tinggi (12 $\mathrm{g} / \mathrm{l})$. Sebab, batas maksimum konsentrasi natrium di reaktor anaerob konvensional, menurut Speece (1996), adalah $5.000 \mathrm{mg} / \mathrm{l}$. Sedangkan pada reaktor high rate, menurut pakar bioproses ini, dibolehkan hingga $15.000 \mathrm{mg} / \mathrm{l}$ dengan satu syarat, adaptasi biomassanya sudah baik.

Selanjutnya adalah tahap dua, dengan resirkulasi. Pada tahap ini Rehan diberikan resirkulasi efluen dengan rasio $\mathrm{R} 1=0,71$ dan $\mathrm{R} 2=1,58$ seperti pada Tabel 4 . 
Tabel 4. Efisiensi pengolahan dengan resirkulasi lumpur

\begin{tabular}{|c|c|c|c|}
\hline $\begin{array}{c}\text { Beban organik } \\
\text { (COD, } \mathrm{mg} / \mathrm{l})\end{array}$ & $\begin{array}{c}\text { Rasio } \\
\text { resirkulasi }\end{array}$ & $\begin{array}{c}\mathrm{KPO} \\
\mathrm{kg} / \mathrm{m}^{3} \text {.hari }\end{array}$ & $\begin{array}{c}\text { Efisiensi } \\
\%\end{array}$ \\
\hline 10.330 & 0,71 & 8,26 & 85,72 \\
\hline 11.755 & 1,58 & 9,40 & 79,88 \\
\hline
\end{tabular}

Beban organik pada tabel 4 ialah nilai COD di tangki umpan (fresh feed). Adapun COD campuran yang masuk ke reaktor dipengaruhi juga oleh COD di aliran resirkulasi yang diasumsikan mendekati nilai efluen reaktor sehingga nilainya menjadi lebih rendah daripada COD di tangki umpan. Namun biasanya nilai COD efluen dianggap nol sehingga rumus yang digunakan ialah COD influen efektif, CODe $=$ COD umpan $/(1+$ $\mathrm{R})$. Simbol $\mathrm{R}$ ini untuk rasio resirkulasi.

\section{Hubungan beban COD, resirkulasi dengan VSS}

Pada modus resirkulasi ini, dosis $\mathrm{NaHCO}_{3}$ sebesar $5 \mathrm{~g} / \mathrm{l}$. Tersaji di Tabel 4, pada rasio resirkulasi 0,71 efisiensi reaktor meningkat menjadi $85,72 \%$ meskipun pada rasio resirkulasi 1,58 efisiensinya turun menjadi $79,88 \%$. Fenomena ini berlawanan dengan teori yang menyatakan bahwa efisiensi pengolahan akan membesar jika rasio resirkulasi terus diperbesar. Itu terjadi karena beban organik influen pada R2 lebih besar dibandingkan dengan R1, yakni $11.755 \mathrm{mg} / \mathrm{L}$ sehingga kecepatan ke atasnya (upflow velocity) membesar, lalu merusak selimut (blanket) mikroba di bagian tersuspensi dan memecah biomassa butir (granular, pellet) menjadi flok atau bahkan suspensi. Henze et.al., (1995) mencatat kisaran kecepatan aliran ke atas ini antara 0,01-0,15 m/jam. Pada penelitian ini nilainya 0,073 $\mathrm{m} / \mathrm{jam}$ (tanpa resirkulasi) dan 0,125 $\mathrm{m} /$ jam (untuk R1) dan 0,189 m/jam (untuk R2). Jadi nilai R2 lebih besar daripada batas atas kisaran kecepatan Henze et.al., (1995).

Alasan di atas didukung oleh data VSS di P1, P2, dan P3 pada Tabel 5 yang lebih rendah daripada VSS ketika debit R1 diterapkan di titik yang sama. Juga tercatat VSS tersuspensi di P4 (pertumbuhan lekat) relatif besar yang artinya terjadi erosi atau kikisan biofilm (erosion washout) pada batu dan VSS yang hanyut (sludge bed washout) akibat dari ekspansi atau kecepatan alirannya yang tinggi. Selain itu, juga karena tingginya akumulasi ion natrium di umpan campuran akibat resirkulasi. Semua hal tadi dapat mengganggu aktivitas mikroba kelompok sensitif, yakni metanogen. 
Tabel 5. Konsentrasi VSS pada variasi COD dan resirkulasi

\begin{tabular}{|c|c|c|c|c|c|}
\hline \multirow{2}{*}{$\begin{array}{c}\text { Titik } \\
\text { sampling }\end{array}$} & \multicolumn{5}{|c|}{ VSS, mg/l } \\
\hline & $\begin{array}{c}10.650 \\
\mathrm{mg} / \mathrm{l}\end{array}$ & $\begin{array}{c}25.200 \\
\mathrm{mg} / \mathrm{l}\end{array}$ & $\begin{array}{c}42.560 \\
\mathrm{mg} / \mathrm{l}\end{array}$ & $\begin{array}{c}10.330 \\
\mathrm{mg} / \mathrm{l}\end{array}$ & $\begin{array}{c}11.755 \\
\mathrm{mg} / \mathrm{l}\end{array}$ \\
\hline efluen & 508 & 540 & 1.020 & 500 & 214 \\
\hline P4 & 800 & 1.580 & 5.650 & 1.300 & 3.957 \\
\hline P3 & 2.562 & 1.820 & 57.450 & 4.035 & 1.520 \\
\hline $\mathrm{P} 2$ & 27.892 & 38.700 & 55.515 & 42.700 & 29.300 \\
\hline $\mathrm{P} 1$ & 28.238 & 39.530 & 55.070 & 49.320 & 41.242 \\
\hline
\end{tabular}

Keterangan:

Pada P4 (pertumbuhan lekat), biomassa terukur hanya yang tersuspensi.

Secara umum, konsentrasi VSS pada mode resirkulasi lebih besar daripada mode tanpa resirkulasi. Namun ada kejanggalan pada beban $42.560 \mathrm{mg} / \mathrm{l}$ karena VSS-nya sangat tinggi melebihi konsentrasi VSS pada beban-beban yang lain namun efisiensinya justru paling rendah. Ini disebabkan oleh konsentrasi asidogennya lebih besar daripada metanogen yang ditunjukkan oleh persentase metananya yang rendah, hanya $41,65 \%$.

Selanjutnya disajikan profil COD pada variasi beban organik yang polanya mengikuti pola evolusi COD pada reaktor aliran tusukan (plug flow). Pada Gambar 1 gradien dari titik influen ke titik P1 $(22,5 \mathrm{~cm})$ sangat besar. Inilah zone paling aktif dan degradasinya cepat. Nilai gradien terendah ini terjadi saat beban organik $10.650 \mathrm{mg} / \mathrm{l}$ karena konsentrasi VSS relatif kecil dan reaktor belum lama beroperasi (beban pertama setelah start up). Sedangkan gradien pada beban $25.200 \mathrm{mg} / \mathrm{l}$ lebih besar daripada beban pertama karena VSS-nya lebih besar sehingga lebih banyak mikroba yang mendegradasi substrat. Untuk beban $42.560 \mathrm{mg} / \mathrm{l}$, gradiennya besar namun mulai terjadi inhibisi. Proses asidogenesis melaju cepat tetapi metanogen terinhibisi oleh natrium dan produk intermediate asam-asam volatil dan $\mathrm{CO}_{2}$.

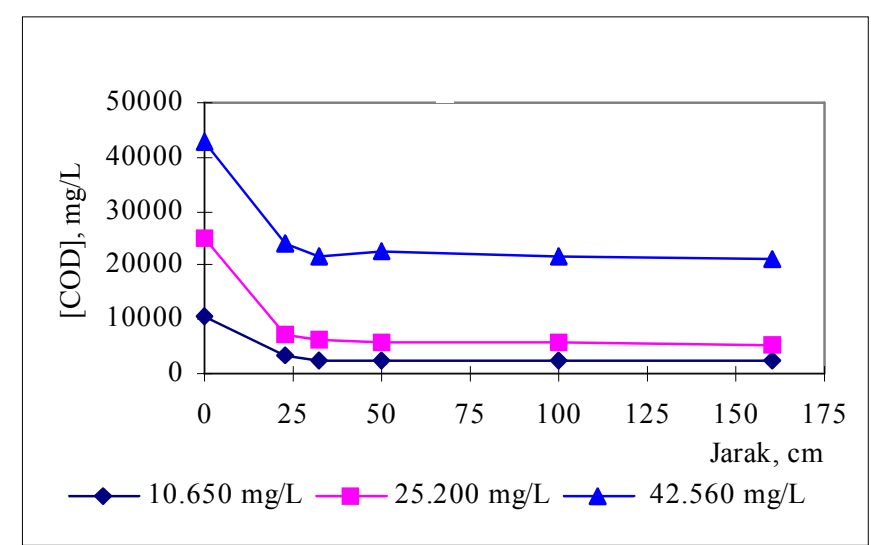

Gambar 1. Profil COD tanpa resirkulasi pada Rehan 
Berikut ini adalah fenomena reaktor dengan resirkulasi, diperlihatkan pada Gambar 2. Gradien pada kedua nilai resirkulasi, antara titik influen dengan P1 $(22,5 \mathrm{~cm})$ sangat besar, bahkan lebih curam daripada gradien profil di Gambar 1. Artinya, resirkulasi meningkatkan laju penyisihan COD. Setelah titik P1, pada kedua gambar tersebut, gradiennya hampir nol yang berarti proses degradasi berjalan lamban atau hampir tidak ada penyisihan COD.

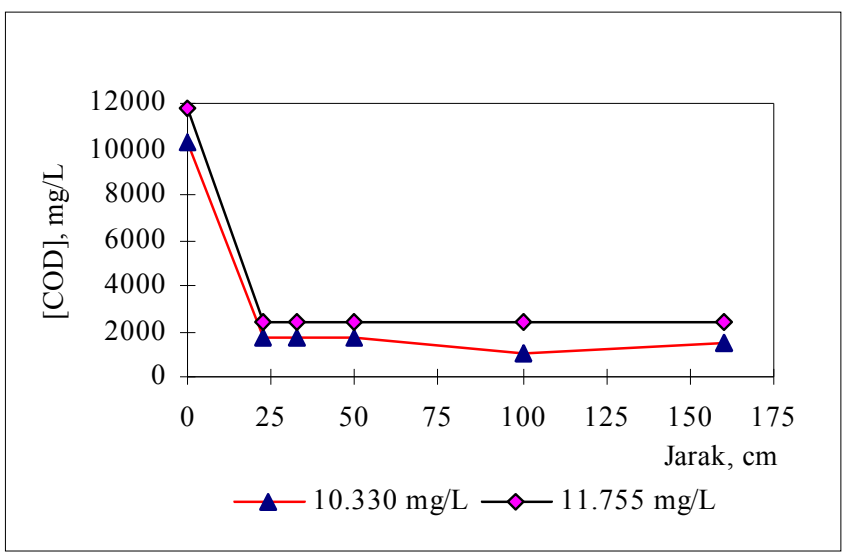

Gambar 2. Profil COD dengan resirkulasi pada Rehan

Dari kedua gambar di atas terlihat bahwa profil COD memiliki kecenderungan yang sama, yaitu menurun ke arah efluen. Inilah yang mengindikasikan rezim aliran reaktor sebagai sebuah sistem berupa plug flow meskipun partisinya masing-masing dapat diasumsikan sebagai reaktor teraduk sempurna.

Untuk profil biomassa (VSS) tersuspensi di sepanjang reaktor pada mode tanpa resirkulasi, bisa dilihat pada Gambar 3.

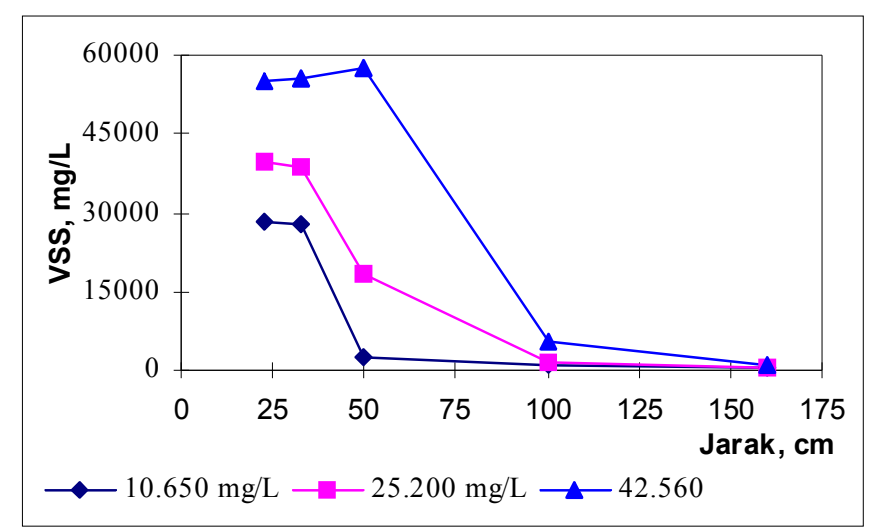

Gambar 3. Profil VSS Rehan pada modus tanpa resirkulasi 
Umumnya (kecuali beban $42.560 \mathrm{mg} / \mathrm{l}$ ), VSS di P1 dan P2 tak jauh berbeda. Gradiennya relatif kecil. Namun setelah P2 terjadi penurunan tajam konsentrasi VSS. Artinya, mikroba sudah membiobutirkan diri (granular sludge) sehingga menjadi berat dan mengendap di bagian bawah reaktor. Ini juga mendukung degradasi COD yang cepat di zone aktif bawah reaktor. Namun setelah P3, gradiennya relatif landai yang berarti penurunan konsentrasi VSS tidak terlalu tajam sehingga degradasi COD pun relatif kecil (zone lamban).

Perkecualian terjadi pada beban organik $42.560 \mathrm{mg} / \mathrm{l}$ atau KPO 34,05 kg/m3.hari yakni konsentrasi VSS justru naik di P1, P2 dan P3 (bagian tersuspensi). Hal ini sekali lagi membuktikan bahwa VSS didominasi oleh asidogen yang tumbuh cepat pada beban organik tinggi. Didukung pula oleh konsentrasi asam volatilnya yang sangat tinggi dan sekaligus penurunan produksi metana.

Selanjutnya adalah profil VSS pada mode resirkulasi yang diperlihatkan pada Gambar 4 di bawah ini.

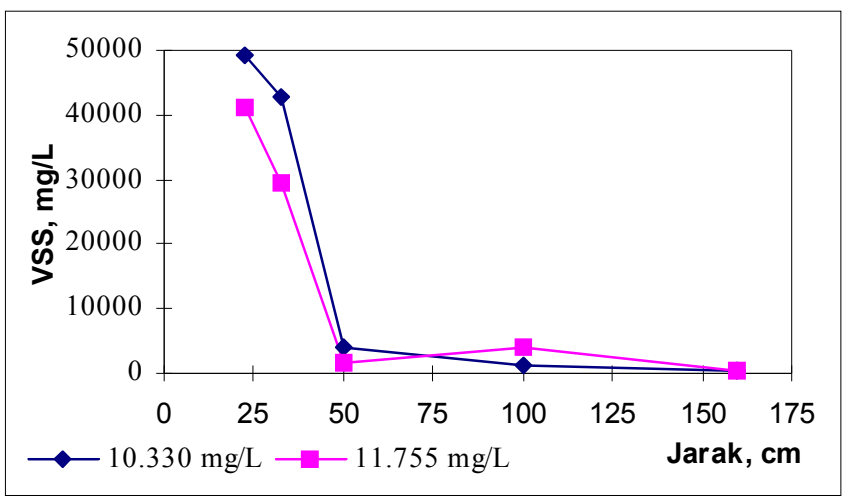

Gambar 4. Profil VSS Rehan pada modus dengan resirkulasi

Pada Gambar 4 terlihat bahwa konsentrasi VSS tertinggi terjadi di titik P1 pada rasio resirkulasi $\mathrm{R} 1=0,71$. Pada beban inilah diperoleh efisiensi terbesar. Namun konsentrasinya turun tajam setelah P2. Alasannya sama dengan sebelumnya, yakni mikroba yang berbentuk biobutir cepat mengendap, menjadikannya aktif mendegradasi substrat di segmen bawah Rehan. 


\section{Kesimpulan}

Pada beban yang relatif tinggi, yaitu $25.000 \mathrm{mg} / \mathrm{l} \mathrm{COD}$ atau KPO $20 \mathrm{~g} / \mathrm{l}$.hari, Rehan mampu mencapai efisiensi sekitar $80 \%$ dan lebih besar lagi pada mode resirkulasi. Bahkan di zone bawah reaktor yang konsentrasi VSS-nya memang sangat tinggi, telah terjadi reduksi COD hingga $65 \%$. Hasil ini memberikan indikasi bahwa media lekat tidak perlu terlalu tebal, cukup dapat menahan laju washout bioflok dan disesuaikan dengan kecapatan aliran air ke atas (upflow velocity).

\section{Daftar Pustaka}

1. Droste, R.L, (1997), Theory And Practice Of Water \& Wastewater Treatment, John Wiley \& Sons. Inc.

2. Henze M., et al (1995), Wastewater Treatment. Biological and Chemical Processes. Springer-Verlag, Berlin, Germany.

3. Lettinga, G, Hulshof Pol (1991). "Application of Modern High Rate Anaerobic Treatment Processes for Wastewater Treatment." New Development in Industrial Wastewater. Series E, Vol. 191, Ed. Turkman, A., O. Uslu. Kluwer Academic Publishers.

4. Ozturk I., et al. (1993). "Hybrid Upflow Anaerobic Sludge Blanket Reactor (HUASBR) Treatment of Dairy Effluents." Wat. Sci. Tech., Vol. 28, p. 77-85.

5. Speece R.E. (1996). Anaerobic Biotechnology for Industrial Wastewater. Archae Press, Vanderbilt University, England.

6. van Lier. (1995). Thermophilic Anaerobic Wastewater Treatment: Temperatur Aspect and Process Stability. Ph.D Thesis, Wageningen Agricultural University, The Netherlands

Dipublikasikan di jurnal ISTEK, Volume III, hIm. 59-66, Bulan Juni 2009. ISSN 1979-8911 